\title{
PENGARUH KEKUATAN BALOK INDUK TERHADAP DIMENSI BALOK ANAK PADA BETON BERTULANG
}

\author{
Tahan \\ Program Studi Teknik Sipil, Fakultas Teknik, Universitas Kristen Palangka Raya \\ E-mail: utuntahan10@gmail.com
}

\begin{abstract}
ABSTRAK
Beton secara umum digolongkan menjadi dua golongan yaitu mutu normal dan mutu tinggi. Sampai saat ini banyak dipakai dalam pembangunan. Beton mutu normal berkisar antara $20 \mathrm{Mpa}-58 \mathrm{Mpa}$, sedangkan beton mutu tinggi berkisar di atas $58 \mathrm{Mpa}$. Aplikasi dalam struktur bangunan salah satunya adalah dimensi dan letak balok anak terhadap kekuatan balok induk dalam suatu struktur bangunan gedung bertingkat. Untuk menganalisa pengaruh balok anak terhadap balok induk dan Finite Element Analysis (FEA) menggunakan ANSYS dengan SOLID65, SOLID45, LINK8 dengan ukuran balok induk dan balok anak yang berbeda-beda dengan ukuran balok induk tipe A ukuran 30/40 dan balok anak ukuran masing-masing 20/40, 25/40, 30/40, balok induk tipe B dengan ukuran 30/50, balok anak ukurannya 25/50, 25/40, 25/35 dan balok induk tipe C dengan ukuran 40/60 dengan ukuran balok anak 35/60, 35/50, 35/40. Material baja yang digunakan mempunyai tegangan utama masing-masing untuk tegangan tulangan utama $400 \mathrm{Mpa}$, tegangan tulangan sengkang $200 \mathrm{Mpa}$, tegangan mutu beton normal $25 \mathrm{Mpa}$, tegangan perletakkan $400 \mathrm{Mpa}$, modulus elastisitas baja 200.000 Mpa. Berdasarkan FEA didapatkan perbandingan pengaruh balok anak terhadap balok induk untuk beban terpusat dari hasil perbandingan tipe A, B dan C tipe yang memiliki kemampuan memikul beban terpusat yang tinggi adalah tipe $\mathrm{C}$ dengan beban terpusat yang mampu dipikulnya sebesar $69,000 \mathrm{kN}$ dengan deformasi yang terjadi sebesar $74,000 \mathrm{~mm}$ dan pengaruh tegangan terjadi sebesar $18,710 \mathrm{Mpa}$ dengan penyebaran gaya yang kurang baik, untuk mengatasi penyebaran gaya yang baik maka beban yang dipikulnya harus sebesar $70 \%$ dari $69.000 \mathrm{kN}$, pada balok tipe C dengan ukuran balok induk 40/60 dan balok anak dengan ukuran 35/60 sehingga dapat disimpulkan bahwa balok induk dan balok anak harus mempunyai dimensi tinggi yang sama tapi lebar balok anak lebih kecil dari balok induk dengan beban yang dipikulnya 70 $\%$ dari beban maksimum.
\end{abstract}

Kata Kunci : Beton mutu normal, Beban maksimum, Deformasi, Tipe balok induk dan balok anak

\begin{abstract}
Generally, concrete can be categorized into normal quality concrete and high quality concrete, both are commonly used in construction. Normal quality concrete has approximately $20 \mathrm{MPa}$ to $58 \mathrm{MPa}$ quality, while the high quality concrete has higher than $58 \mathrm{MPa}$. One of the applications of these concrete in structure is the dimension and joist position toward the beam's strength in a storey structure.To analyse the effect of joist toward beam, Finite Element Analysis (FEA)is applied with the following: Utilizing ANSYS with SOLID65, SOLID45, LINK8 with varying size of joist and beam such as type A beam by the size of 30/40 and joist by the size of 20/40, 25/40,30/40, type B beam by the size of 30/50 and joist size of 25/50, 25/40, 25/35 and type C beam by the size of 40/60 and the joist size of 35/60, 35/50, 35/40. Steel material being used each has 400 $\mathrm{MPa}$ for the main reinforcement tension, $200 \mathrm{MPa}$ for the stirrup reinforcement, normal quality concrete tension of $25 \mathrm{MPa}$, placement tension of $400 \mathrm{MPa}$, steel modulus elasticity of 200,000 MPa. Based on the FEA it is obtained that the comparison of joist influence toward the beam is centered from the comparison result of
\end{abstract}


type $A, B$, and $C$ where the type that has the capacity to sustain focused weight is type $C$, with focused weight capacity of $69.2000 \mathrm{kN}$ with $74.000 \mathrm{~mm}$ deformation and $18.710 \mathrm{MPa}$ tension effect with less efficient force distribution. To improve the force distribution, the sustained weight must be 70 percent of $69.000 \mathrm{kN}$ in type $C$ with 40/60 beam size and 35/60 joist size. It is concluded that the beam and joist must have the same height dimension but the joist's width must be smaller than the beam, while the sustained weight is 70 percent of the maximum weight.

Keywords: Normal quality concrete, maximum weight, deformation, type of beam and joist.

\section{PENDAHULUAN}

Beton adalah material konstruksi yang banyak dipakai sampai saat ini dibandingkan dengan material lain seperti kayu dan baja. Hal ini dikarenakan material penyusunnya mudah didapat, mempunyai kekuatan yang cukup kuat, keawetan, proses pembuatannya mudah dan segi keekonomisan harganya terjangkau. Beton secara umum digolongkan menjadi dua golongan, yaitu beton mutu normal dan beton mutu tinggi. Beton mutu normal adalah beton yang mempunyai mutu berkisar $20 \mathrm{Mpa}$ sampai dengan $58 \mathrm{Mpa}$ dan dibuat menggunakan agregat alam yang dipecah atau tanpa dipecah. Sedangkan beton mutu tinggi adalah beton yang mempunyai mutu diatas $58 \mathrm{Mpa}$ dan dibuat menggunakan agregat alam yang dipecah atau agregat buatan dengan campuran bahan tambah (additive) serta metode pelaksanaan yang disesuaikan dengan kebutuhan kuat tekannya (SNI-03-2847-2002).

Dalam penelitian ini, dirumuskan permasalahan analisis pengaruh variasi dimensi lebar balok anak terhadap kekuatan balok induk pada portal beton bertulang dengan tinggi balok anak sama dengan tinggi balok induk, serta analisis pengaturan dimensi letak balok anak, dan perilaku keruntuhan balok induk dengan variasi tinggi balok anak terhadap sisi atas dan bawah balok induk.

Tujuan dalam penelitian adalah untuk mengetahui pengaruh variasi dimensi lebar balok anak terhadap kekuatan balok induk pada portal beton bertulang dengan tinggi balok anak sama dengan tinggi balok induk. Serta untuk mengetahui dimensi letak balok anak, dan perilaku keruntuhan balok induk dengan variasi tinggi balok anak terhadap sisi atas dan bawah balok induk.

\section{METODE PENELITIAN}

Penelitian ini dilakukan dengan memodelkan balok induk dan anak beton bertulang dengan menggunakan analisis metode tiga dimensi elemen hingga dengan bantuan komputasi ANSYS Hasil analisis yang akan diperoleh berupa nodal displacement, elemen gaya and momen, lendutan dan diagram stress contour. Analisis ini akan menggambarkan perilaku keretakan dan keruntuhan.

Analisis permodelan ini dilakukan untuk mengetahui dan memprediksi kemajuan balok induk menerima pembebanan terpusat ultimit dan perilaku keretakan balok induk dalam beberapa model balok anak, sehingga variasi-variasi dan jumlah luas tulangan longitudinal yang digunakan disepanjang bentang balok induk dan anak. Hasil permodelan ini akan menggambarkan masingmasing perilaku balok induk dengan beberapa model balok anak

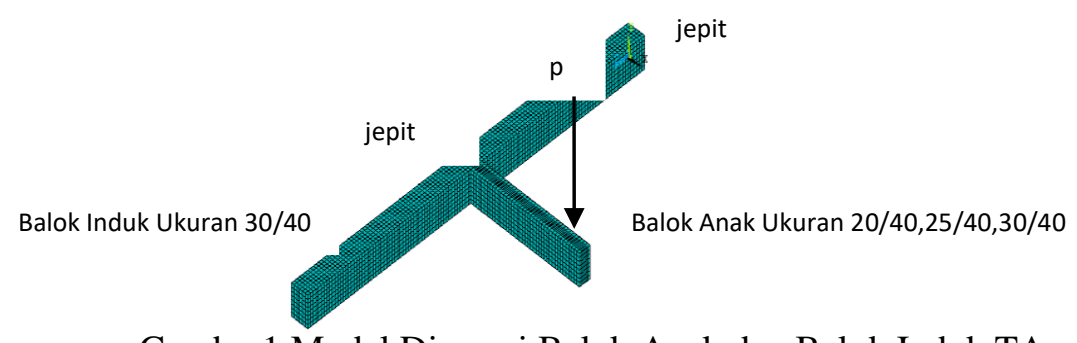

Gambar1 Model Dimensi Balok Anak dan Balok Induk TA 


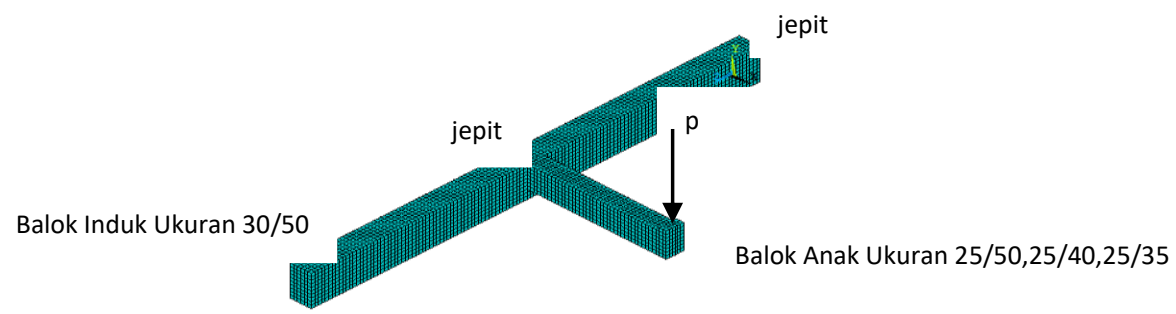

Gambar 2 Model Dimensi Balok Anak dan Balok Induk TB

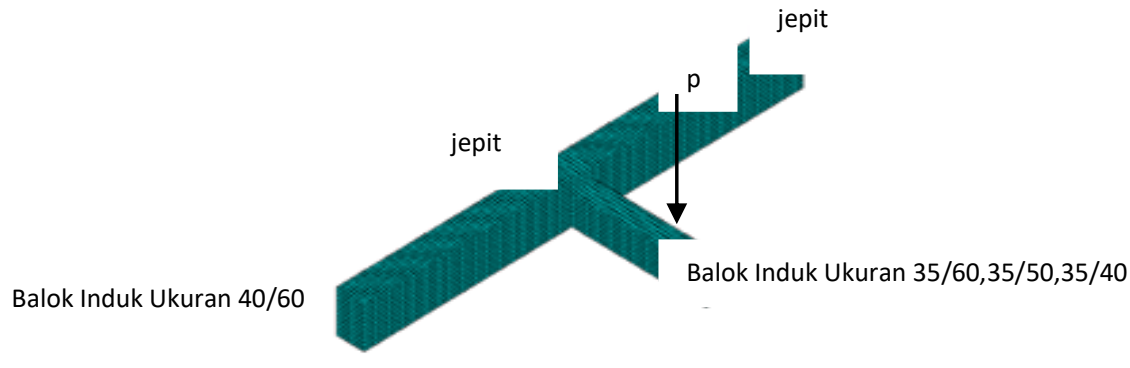

Gambar 3 Model Dimensi Balok Anak dan Balok Induk TC

\section{HASIL DAN PEMBAHASAN}

Validasi Hasil Model Balok Induk dan Anak Menggunakan ANSYS dengan Hasil Eksperimental Terdahulu. Analisis awal pemodelan ini adalah pemodelan balok Induk dan anak dengan input data yang sesuai dengan sampel balok uji Eksperimental. Model kemudian di analisis menggunakan ANSYS dan hasilnya akan dibandingkan dengan hasil uji eksperimental. Apabila hasil sudah tervalidasi maka akan dilanjutkan dengan implementasi model balok induk dan anak dengan variasi yang telah ditetapkan dalam batasan penelitian sebelumnya. Poin penting hasil eksperimental tersebut yaitu rasio balok induk dan anak yang sama ketinggiannya mampu memikul beban ultimit dan kejelekannya balok induk bersifat getas.

Hasil Model Eksperimental dengan Menggunakan ANSYS model balok iduk dan anak hasil eksperimental akan dianalisis dengan elemen hingga menggunakan program komputasi ANSYS akan dibandingkan dengan hasil eksperimental untuk mendapatkan suatu pola tegangan balok induk dan anak yang mendekati dengan hasil uji eksperimental

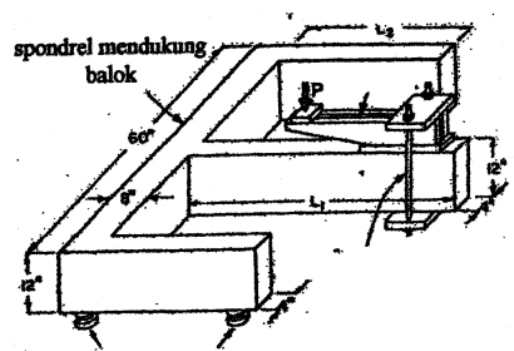

Gambar 4 Tes Uji Eksperimental (A. H. Mattock and J.F. Shen, 1992)

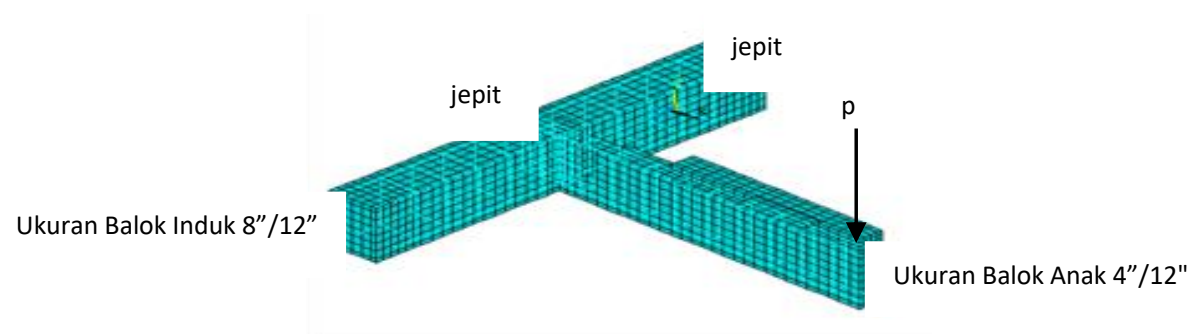

Gambar 5 Hasil Model Eksperimental dengan menggunakan ANSYS 
Tabel 1 Hasil Validasi ANSYS dengan Ekperimental terdahulu

\begin{tabular}{ccc}
\hline Keterangan & Ekperimental terdahulu & ANSYS Validasi \\
\hline$F \max$ & $31,640 \mathrm{Mpa}$ & $31,814 \mathrm{Mpa}$ \\
\hline Pmax & $36,401 \mathrm{kN}$ & $36,500 \mathrm{kN}$
\end{tabular}

berapa besar pengaruhnya beban, deformasi,tegangan dan pola retak beton pada sembilan model yang akan dianalisis. Dapat dilihat pada tabel dan gambar grafik di bawah ini

Tabel 2. Gabungan Beban Terpusat dan Deformasi Model A

\begin{tabular}{|c|c|c|c|c|c|}
\hline $\begin{array}{c}\text { Deformasi } \\
(\mathrm{mm})\end{array}$ & $\begin{array}{c}\text { Beban } \\
\text { Terpusat } \\
(\mathrm{KN})\end{array}$ & $\begin{array}{c}\text { Deformasi } \\
(\mathrm{mm})\end{array}$ & $\begin{array}{c}\text { Beban } \\
\text { Terpusat } \\
(\mathrm{KN})\end{array}$ & $\begin{array}{c}\text { Deformasi } \\
(\mathrm{mm})\end{array}$ & $\begin{array}{c}\text { Beban } \\
\text { Terpusat } \\
(\mathrm{KN})\end{array}$ \\
\hline \multicolumn{2}{|c|}{ TA-20.40 } & \multicolumn{2}{|c|}{ TA-25.40 } & \multicolumn{2}{c|}{ TA-30.40 } \\
\hline 0 & 0 & 0 & 0 & 0 & 0 \\
\hline 1,98004 & 4,2 & 1,291 & 2,705 & 1,46563 & 2,2 \\
\hline 3,96008 & 8,4 & 2,58201 & 5,41 & 2,93125 & 4,4 \\
\hline 6,51521 & 12,6 & 3,87301 & 8,115 & 4,39688 & 6,6 \\
\hline 9,3858 & 16,8 & 6,5606 & 10,82 & 7,56291 & 8,8 \\
\hline 15,1703 & 21 & 9,74883 & 13,525 & 11,4998 & 11 \\
\hline 22,8015 & 25,2 & 13,9138 & 16,23 & 19,0664 & 13,2 \\
\hline 36,9509 & 29,4 & 23,0663 & 18,935 & 28,1773 & 15,4 \\
\hline 50,5559 & 33,6 & 35,755 & 21,64 & 41,916 & 17,6 \\
\hline 66,9792 & 37,8 & 59,3224 & 24,345 & 68,5511 & 19,8 \\
\hline 94,665 & 42 & 174,894 & 27,05 & 127,523 & 22 \\
\hline
\end{tabular}

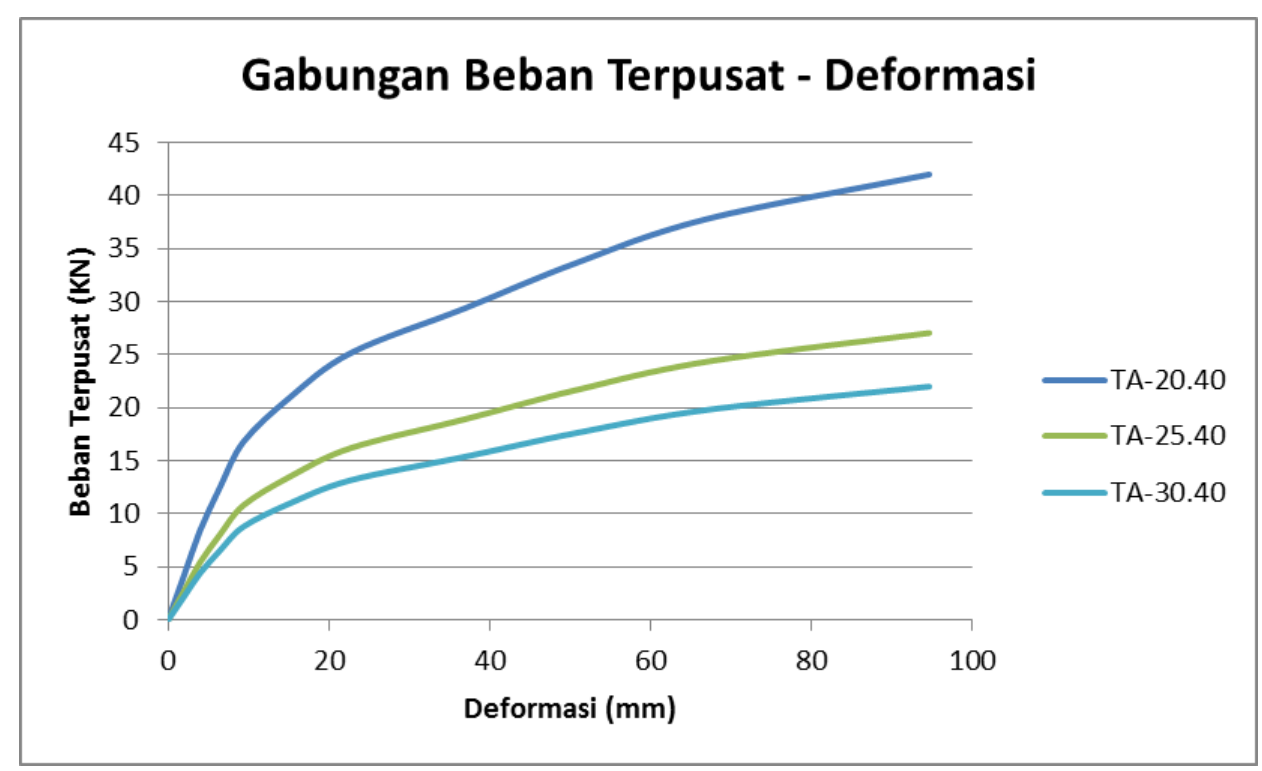

Gambar 6. Grafik Gabungan Model A

Tabel 3. Gabungan Beban Terpusat dan Deformasi Model B

\begin{tabular}{|c|c|c|c|c|c|}
\hline $\begin{array}{c}\text { Deformasi } \\
(\mathrm{mm})\end{array}$ & $\begin{array}{c}\text { Beban } \\
\text { Terpusat } \\
(\mathrm{KN})\end{array}$ & $\begin{array}{c}\text { Deformasi } \\
(\mathrm{mm})\end{array}$ & $\begin{array}{c}\text { Beban } \\
\text { Terpusat } \\
(\mathrm{KN})\end{array}$ & $\begin{array}{c}\text { Deformasi } \\
(\mathrm{mm})\end{array}$ & $\begin{array}{c}\text { Beban } \\
\text { Terpusat } \\
(\mathrm{KN})\end{array}$ \\
\hline \multicolumn{2}{|c|}{ TB-25.50 } & \multicolumn{2}{c|}{ TB-25.40 } & \multicolumn{2}{c|}{ TB-25.35 } \\
\hline 0 & 0 & 0 & 0 & 0 & 0 \\
\hline 1,0759 & 3,5 & 0,910913 & 2,605 & 0,867593 & 2,205 \\
\hline 2,15179 & 7 & 1,82183 & 5,21 & 1,73519 & 4,41 \\
\hline
\end{tabular}




\begin{tabular}{|c|c|c|c|c|c|}
\hline $\begin{array}{c}\text { Deformasi } \\
(\mathrm{mm})\end{array}$ & $\begin{array}{c}\text { Beban } \\
\text { Terpusat } \\
(\mathrm{KN})\end{array}$ & $\begin{array}{c}\text { Deformasi } \\
(\mathrm{mm})\end{array}$ & $\begin{array}{c}\text { Beban } \\
\text { Terpusat } \\
(\mathrm{KN})\end{array}$ & $\begin{array}{c}\text { Deformasi } \\
(\mathrm{mm})\end{array}$ & $\begin{array}{c}\text { Beban } \\
\text { Terpusat } \\
(\mathrm{KN})\end{array}$ \\
\hline 3,22769 & 10,5 & 2,73285 & 7,815 & 2,60298 & 6,615 \\
\hline 5,23009 & 14 & 4,9051 & 10,42 & 5,06314 & 8,82 \\
\hline 7,42141 & 17,5 & 7,22543 & 13,025 & 8,20844 & 11,025 \\
\hline 10,0928 & 21 & 10,2379 & 15,63 & 11,8334 & 13,23 \\
\hline 16,6329 & 24,5 & 14,7588 & 18,235 & 16,8869 & 15,435 \\
\hline 23,9594 & 28 & 20,6927 & 20,84 & 26,8923 & 17,64 \\
\hline 35,5871 & 31,5 & 34,5271 & 23,445 & 51,7629 & 19,845 \\
\hline 53,639 & 35 & 58,1558 & 26,05 & 91,6798 & 22,05 \\
\hline
\end{tabular}

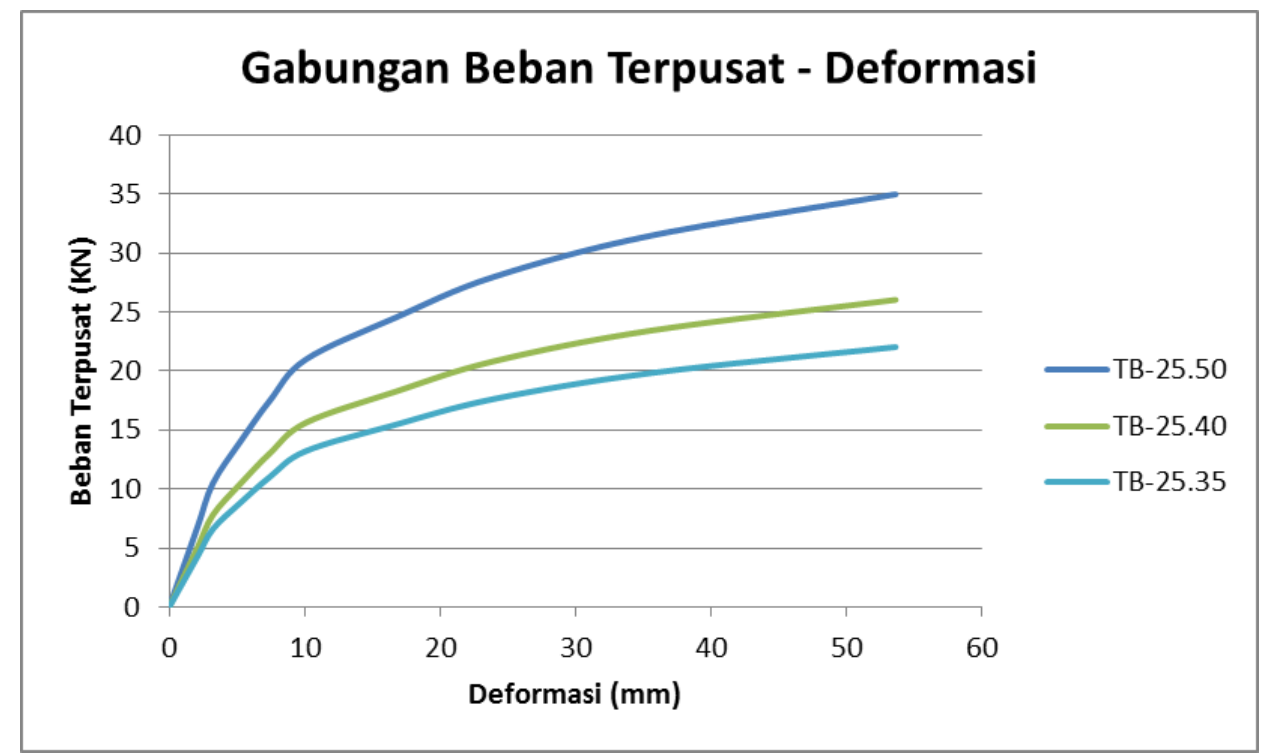

Gambar 7. Grafik Gabungan Model B

Tabel 4. Gabungan Beban Terpusat dan Deformasi Model C

\begin{tabular}{|l|l|l|l|l|l|}
\hline $\begin{array}{l}\text { Deformasi } \\
(\mathrm{mm})\end{array}$ & $\begin{array}{l}\text { Beban } \\
\text { Terpusat } \\
(\mathrm{KN})\end{array}$ & $\begin{array}{l}\text { Deformasi } \\
(\mathrm{mm})\end{array}$ & $\begin{array}{l}\text { Beban } \\
\text { Terpusat } \\
(\mathrm{KN})\end{array}$ & $\begin{array}{l}\text { Deformasi } \\
(\mathrm{mm})\end{array}$ & $\begin{array}{l}\text { Beban } \\
\text { Terpusat } \\
(\mathrm{KN})\end{array}$ \\
\hline TC-35.60 & & TC-35.50 & & TB-35.40 & \multicolumn{1}{|l|}{} \\
\hline 0 & 0 & 0 & 0 & 0 & 0 \\
\hline 0,869923 & 6,9 & 0,699827 & 5 & 0,517724 & 3 \\
\hline 1,73985 & 13,8 & 1,39965 & 10 & 1,03545 & 6 \\
\hline 2,60977 & 20,7 & 2,68084 & 15 & 1,55317 & 9 \\
\hline 4,6259 & 27,6 & 4,87238 & 20 & 3,78361 & 12 \\
\hline 7,1739 & 34,5 & 7,82812 & 25 & 5,56237 & 15 \\
\hline 12,5444 & 41,4 & 13,7305 & 30 & 8,86671 & 18 \\
\hline 21,3169 & 48,3 & 21,9667 & 35 & 14,6093 & 21 \\
\hline 31,1453 & 55,2 & 32,2787 & 40 & 23,8695 & 24 \\
\hline 45,2143 & 62,1 & 51,9003 & 45 & 36,3229 & 27 \\
\hline 73,9993 & 69 & 88,6732 & 50 & 73,6511 & 30 \\
\hline
\end{tabular}




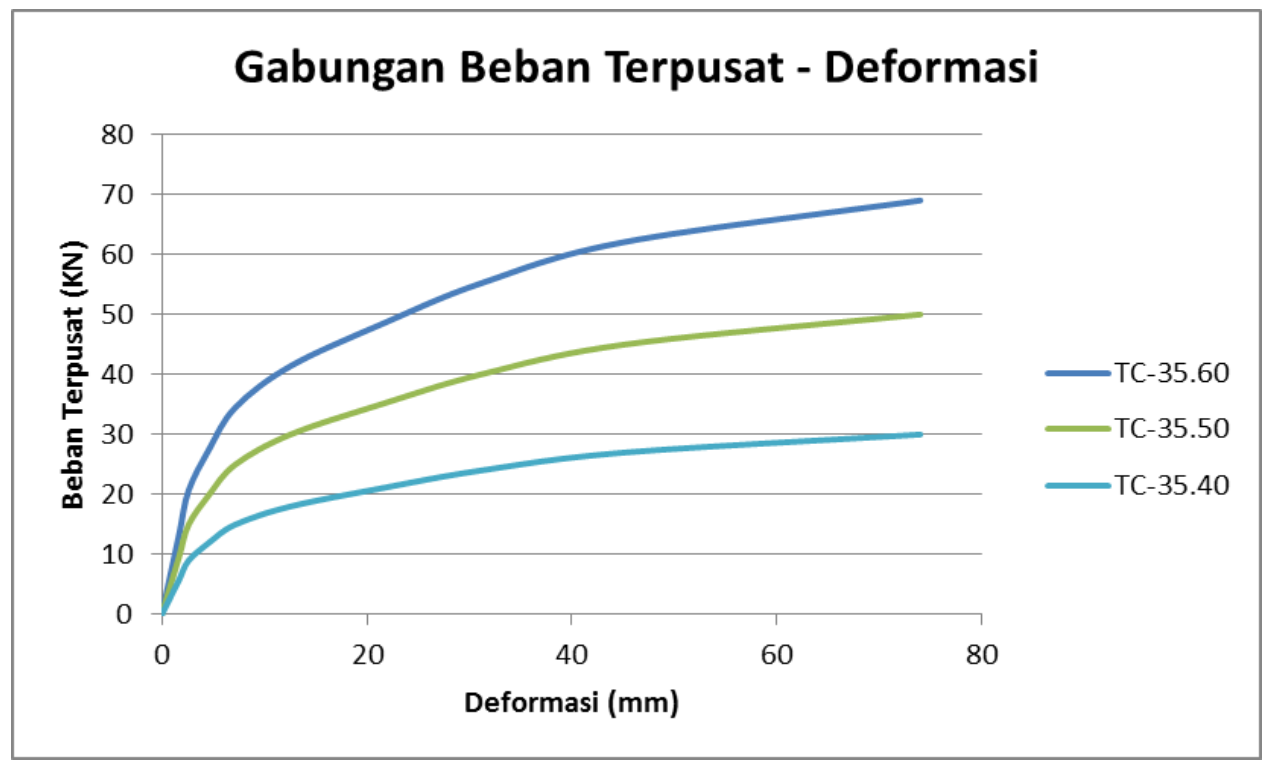

Gambar 8. Grafik Gabungan Model C

Tabel 5. Gabungan Tegangan Von Misses dan Deformasi Model C

\begin{tabular}{|c|c|c|c|c|c|}
\hline $\begin{array}{c}\text { Deformasi } \\
(\mathrm{mm})\end{array}$ & $\begin{array}{c}\text { Tegangan Von } \\
\text { Misses (MPa) }\end{array}$ & $\begin{array}{c}\text { Deformasi } \\
(\mathrm{mm})\end{array}$ & $\begin{array}{c}\text { Tegangan } \\
\text { Von Misses } \\
(\mathrm{MPa})\end{array}$ & $\begin{array}{c}\text { Deformasi } \\
(\mathrm{mm})\end{array}$ & $\begin{array}{c}\text { Tegangan } \\
\text { Von Misses } \\
(\mathrm{MPa})\end{array}$ \\
\hline \multicolumn{2}{|c|}{ TC-35.60 } & \multicolumn{2}{|c|}{ TC-35.50 } & \multicolumn{2}{c|}{ TC-35.40 } \\
\hline 0 & 0 & 0 & 0 & 0 & 0 \\
\hline 0,869923 & 0,471791 & 0,699827 & 0,492035 & 0,517724 & 0,489887 \\
\hline 1,73985 & 0,943582 & 1,39965 & 0,984069 & 1,03545 & 0,979775 \\
\hline 2,60977 & 1,41537 & 2,68084 & 1,48084 & 1,55317 & 1,46966 \\
\hline 4,6259 & 1,95749 & 4,87238 & 2,05494 & 3,78361 & 1,98448 \\
\hline 7,1739 & 2,59926 & 7,82812 & 2,83672 & 5,56237 & 2,53851 \\
\hline 12,5444 & 3,94337 & 13,7305 & 4,31281 & 8,86671 & 4,4081 \\
\hline 21,3169 & 9,12076 & 21,9667 & 8,3858 & 14,6093 & 7,88913 \\
\hline 31,1453 & 12,6091 & 32,2787 & 11,4047 & 23,8695 & 9,23807 \\
\hline 45,2143 & 14,7147 & 51,9003 & 15,2827 & 36,3229 & 13,3003 \\
\hline 73,9993 & 18,7134 & 88,6732 & 18,7387 & 73,6511 & 19,3642 \\
\hline
\end{tabular}

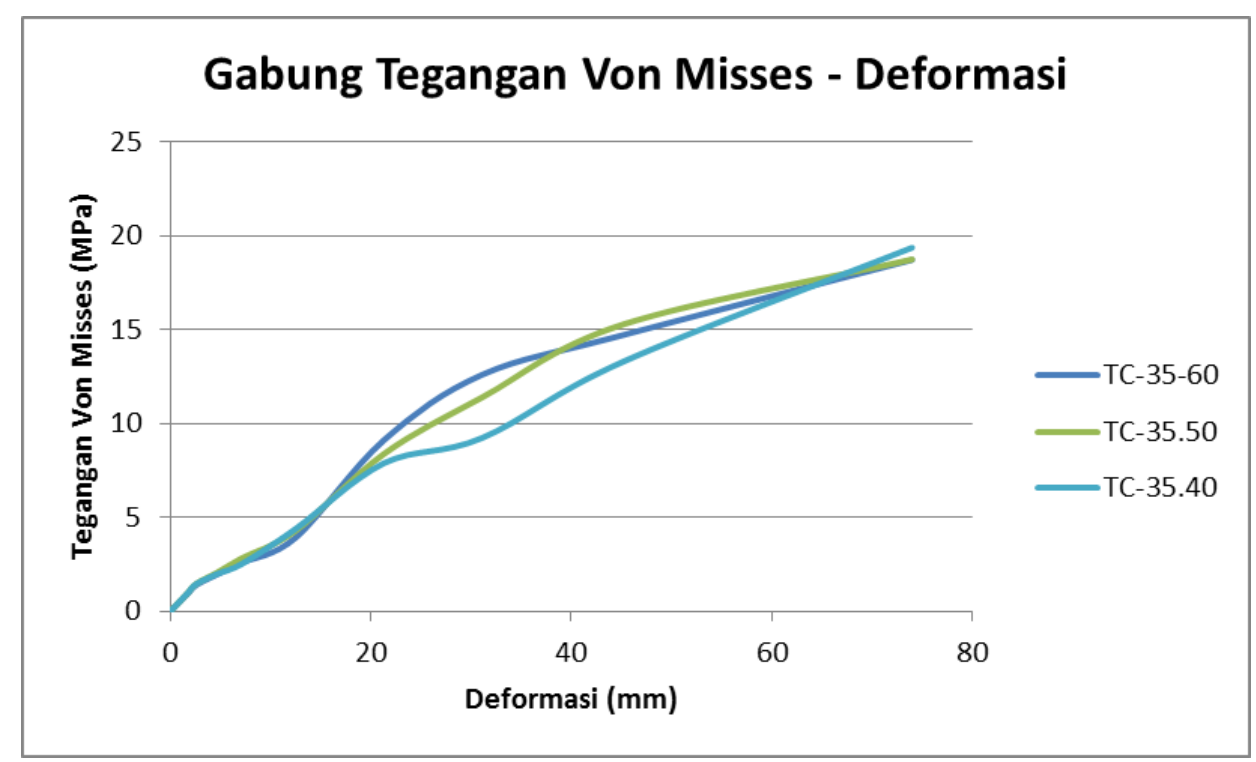

Gambar 9. Grafik Gabungan Model C 


\section{PENUTUP}

\section{Kesimpulan}

Balok induk dan balok anak harus mempunyai dimensi tinggi yang sama tetapi lebar balok anak lebih kecil dari balok induk dengan persentase lebar balok anak 12,5 persen kurangnya dari lebar balok induk dan Berdasarkan penyebaran retak pertama pada balok induk dari permodelan dalam uji coba ini, maka dapat diambil penyebaran retak model tipe $\mathrm{C}$ (variasi tinggi balok anak terhadap sisi bawah balok induk) dengan ukuran balok induk 40/60 dan balok anak 35/60 dimana menghasilkan kemampuan menahan beban terpusat sebesar $69,000 \mathrm{kN}$, deformasi sebesar 74,000 mm dan tegangan Von Misses sebesar 18,710 Mpa. Untuk menghasilkan pola retak yang baik maka beban yang bekerja sebaiknya 48,300 kN.

\section{DAFTAR PUSTAKA}

Mattock, A.H., dan Shen, J.F. (1992). ACI Jurnal Struktur

ANSYS Release 11. (2007). Programmer's Manual for ANSYS. ANSYS Incorporations and ANSYS Europe, Ltd. (http://ansys.com diakses tanggal 5 September 2009).

Chu-Kia Wang Charles G.Salmon Reinforced Concrete Design, Fourth Edition.

Ese Soedarsono HS, Design and Detailing of Flat Slab, 27 February 2002.

Jack C. Mc Cormac. Desain Beton Bertulang Edisi Kelima Jilid 2 Penerbit Erlangga Jakarta.

Kodur, V.K.R. Bisby, L.A. Evaluation of Fire Endurance of Concrete Slabs Reinforced With FRP Bars. Journal of Structural Engineering. ASCE. 131 (1). 2005. Pp 34-43 (http://link.aip.org diakses tanggal 4 Agustus 2009).

Mac Gregor, J. G. (1997). Reinforced Concrete: Mechanics and Design 3rd Ed. Prentice-Hall International, Inc.

http://www.gussuta.com/teknik/perpustakaanteknik-sipil.html

Matsui. (1997). Tinjauan perilaku tegangan lekat pada struktur beton bertulang dengan Metode Semi Beam dan Pull Out.

Neville, A. Aitcin, P. C. High Performance Concrete-an overview Journal of Material and Structure. 31 March 1998. pp 111-117.
Parvanova, Sonia. L., et al. (2004). Modeling The Nonlinear Behaviour of R/C Beams With Moderate Shear Span and Without Strirrups Using Ansys.National Scienc Fund.Bulgaria

Purwono, R. (2005). Tata Cara Perhitungan Struktur Beton Bertulang Tahan Gempa (SN103-1726-2002). Edisi ketiga ITS Press. Surabaya. Indonesia

Purwono, R. Tavio,Iswandi I, I.Gusti Putu R. Tata Cara Perhitungan Struktur Beton Untuk Bangunan Gedung. (SNI 03-28472002) Dilengkapi Penjelasan [S-2002]. ITS Press. Surabaya. Indonesia

R. Park, W. L. Gamble. (1993). Reinforced Concrete Slabs

Shah, S. P. Ahmad, S.H. (1994). High Performance Concrete: Properties and Applications. Mc Graw-Hill Companies, (http://linkinghub.elsevier.com diakses Tanggal 4 Agustus 2009) 